\title{
Reproduction of Littorina brevicula in Korean waters
}

\author{
Min Ho Son, Sung Yun Hong*
}

Department of Marine Biology, Pukyoung National University, Pusan 608-737, Korea

\begin{abstract}
Littorina brevicula (Philippi) is a small herbivorous gastropod, abundant on most rocky shores of Korea. In spite of its ecological importance as a dominant grazer, few studies have addressed its reproductive biology. The present study reports reproductive characteristics of $L$. brevicula, based on field and laboratory observations and experiments in Pusan, southern Korea. Histological examination showed that minimum size of sexual maturation was about $6.0 \mathrm{~mm}$ shell length in both males and females. Males searched for mates by random movement, and there was no size-assortative mating pattern. The main spawning period was winter (December to April), and the critical seawater temperature to induce spawning was $12.0^{\circ} \mathrm{C}$. Under laboratory conditions, it took $7 \mathrm{~d}$ from spawning to hatching as a veliger larva $\left(11.0\right.$ to $\left.13.0^{\circ} \mathrm{C}\right)$. Mean sizes of the egg capsule and egg were 465 and $135 \mu \mathrm{m}$ respectively and the mean number of eggs produced by a female was 247 (101 to 373)
\end{abstract}

KEY WORDS: Reproduction · Littorina brevicula $\cdot$ Korea

\section{INTRODUCTION}

Littorina brevicula (Philippi) is a common periwinkle in the intertidal region of the rocky, boulder and cobble shores of Korea. Geographic distribution of this species is limited to the boreal Pacific (Rosewater 1970). Its shell shape varies most noticeably on a geographical scale, and 2 principal varieties (var. typica and var. souverbiana) were reported by Reid (1996).

In contrast to morphological and physiological variation, behavioural aspects of sexual selection (e.g. mating behaviour and mating pattern) have been poorly studied in littorinid species. The majority of studies on the behaviour of littorinid species have focused upon population-level movements of periwinkles in relation to tide and/or season (e.g. Abe 1935, Lebour 1945, Kojima 1959, Fretter \& Graham 1962, Struhsaker 1966), and relatively few have examined their movements in relation to reproduction, such as mating and/or sexual selection, at the individual level. Reid (1986) has briefly reviewed the mating behaviour of Littoraria species in mangrove forests of the Indo-

\footnotetext{
•E-mail: syhong@dolphin.pknu.ac.kr
}

Pacific region. Recently, Erlandsson \& Johannesson (1994) reported partial assortative mating with respect to size, and sexual selection on female size, in a Swedish population of Littorina littorea. Takada (1995) reported an assortative mating pattern in Japanese $L$. brevicula whereby mating occurred solely within subpopulations defined by their zonal position on the shore. However, a detailed description of mating behaviour and sexual selection in $L$. brevicula has not been produced to date.

Spawning of Littorina brevicula has been studied by several workers. For example, Kojima $(1957,1960)$ has reported reproductive seasonality in this species, based on plankton samples and observations of mating pairs in Asamushi, northern Japan, and Hirai (1963) noted breeding seasonality in the same area also based on the plankton samples. Kojima (1959) observed the downward winter migration of $L$. brevicula for breeding. Yamaguchi (1967) discussed the relationship between seawater temperature and spawning activity in Misaki, southern Japan. Recently, Takada (1995) reported the mating and spawning periods occurring in winter in Amakusa, southern Japan, as part of his study on the dimorphic migration behaviour of this species. From the foregoing studies it is known that $L$. 
brevicula mates and spawns in winter, during the period of lowest seawater temperature in the year. Temperature is an essential factor in inducing spawning of marine invertebrates, including the family Littorinidae (Webber 1977)

Larval development in the Littorinidae, at least in European species, has been studied extensively. For example, Pelseneer (1911) documented the morphology of the larvae of Littorina obtusata, and Lebour $(1935,1945)$ has described the morphology and size of eggs and larvae of $L$. littorea, L. (= Melaraphe) neritoides, and $L$. ziczac. In the Pacific region, Struhsaker (1966) has described egg and larval size in L. pintado, and Kojima (1957) and Yamaguchi (1967) have documented the morphology and size of the eggs and egg capsules of $L$. brevicula based on plankton samples and laboratory-reared individuals. Mileikovsky (1975) classified the types of larval development of 39 littorinid species based on their habitat in the littoral zone. The utility of egg capsule morphology as a species character in littorinid species has been emphasised by several workers (e.g. Tokioka \& Habe 1953, Abbott 1954, Borkowski \& Borkowski 1969, Reid 1986).

In contrast to our knowledge of many European littorinid species, relatively little is known about the detailed and quantitative reproductive biology of a common boreal Pacific species, Littorina brevicula. Therefore the purpose of the present study is (1) to histologically identify the minimum size at sexual maturation in both sexes, and to examine the (2) mating behaviour and pattern, (3) mating and spawning cycles and period, (4) critical seawater temperature for commencement and cessation of breeding, (5) morphology and size of the egg and egg capsule, (6) larval development, and (7) fecundity of L. brevicula, based on both field-and laboratory-reared specimens.

\section{MATERIALS AND METHODS}

Study site. The study site is located in southeastern Korea $\left(35^{\circ} 02^{\prime} \mathrm{N}, 129^{\circ} 02^{\prime} \mathrm{E}\right)$ and comprises a gently sloping rocky shore with large boulders. The site, which is ca $125 \mathrm{~m}^{2}$ (25 m along the shoreline $\times 5 \mathrm{~m}$ vertically), is moderately exposed, continuously receiving splash and spray from waves except during periods of very calm weather. Surfaces of large boulders in the supra-littoral zone are usually covered by Verrucaria $\mathrm{sp}$. The site contains patches of various algae: Enteromorpha spp., Ulva sp. and Porphyra spp. in upper regions of the mid-littoral zone; Sargassum sp. and Chondrus $\mathrm{sp}$. in middle regions of the latter; and Pachymeniopsis sp., Carpopeltis sp. and Corallina sp. in lower regions of the mid-littoral and/or sub-littoral zones. Mytilus galloprovincialis also dominates on the surfaces of large boulders in the sub-littoral zone. Surface seawater temperature is ca $12.5^{\circ} \mathrm{C}\left(10.5\right.$ to $\left.16.2^{\circ} \mathrm{C}\right)$ in winter (from December to February) and ca $20.0^{\circ} \mathrm{C}$ $\left(17.4\right.$ to $27.9^{\circ} \mathrm{C}$ ) in summer (from June to August). Lowest air temperature in winter seldom falls below freezing point. Tides have a semidiurnal pattern, and the tidal range is ca $80 \mathrm{~cm}$.

Sampling, measuring and observation. Sexual maturation was examined via histological sections to obtain the minimum size of sexual maturation in the male and female. During the main spawning period (December to April), 40 periwinkles of at least $5 \mathrm{~mm}$ in shell length were collected and then fixed in Bouin's solution for $24 \mathrm{~h}$. After fixation, the periwinkles were sorted into several size classes (size class interval: $0.5 \mathrm{~mm}$ ) based on shell length, and the animal removed from its shell using a fine needle. The sex was determined under a stereomicroscope, based on the anatomy of reproductive organs (e.g. pallial oviduct in the female and prostate gland in the male). Parasite infection and imposex were not examined. The fixed specimens were dehydrated in a series of ethyl alcohol. The normal paraffin embedding procedure was followed. The entire soft body, excluding the head-foot, was cut transversely into ca $5 \mu \mathrm{m}$ sections, and stained in hematoxylin followed by eosin as a counterstain. Specimens were classified as sexually mature if mature oocytes (females) or spermatozoa (males) were found in the gonad. Details of oogenesis and vitellogenesis were not examined.

Mating behaviour was observed in the laboratory in January 1994 using 50 active adults of unknown sex. The periwinkles were placed in a transparent glass jar (51 in volume; $40 \mathrm{~cm}$ in diameter) filled with seawater taken from the sampling site, without artificial aeration. Observations were made by eye over a period of $6 \mathrm{~h}$, with particular attention being paid to the matesearching behaviour and copulation duration. After observation the periwinkles were boiled and dissected to identify their sex.

For the analysis of mating patterns, the study site was visjted fortnightly from December 8, 1994 to February 16,1995 . Observations were standardised by visiting the shore during low ebb tide. For $30 \mathrm{~min}$, the number of mating pairs occurring between the supralittoral zone and upper margin of the sub-littoral area (ca $100 \mathrm{~m}^{2}$ ) was counted. When mating pairs were found, they were picked up and separated. After separation, maximum shell length of each periwinkle was measured in situ using digital Vernier callipers. A record of the number of mating pairs was also made fortnightly from March 1994 to April 1995 to clarify the mating period at the sampling site. The monthly sum of the number of mating pairs was used to analyse the mating period. 
To compare the mean size of females within the mating group and a random sample of the population, periwinkles (of unidentified sex) were collected with a quadrat $(1 \times 1 \mathrm{~m})$ from the study site on January 20 , 1995. After sampling, 417 individuals larger than $6.5 \mathrm{~mm}$ in shell length were selected for this study. The size criterion was determined by the fact that sexual maturation of Littorina brevicula was observed only in individuals exceeding $6.5 \mathrm{~mm}$ in shell length (Kojima 1957). In the present study, the mean size of a group of copulating females, defined as the mating group, was compared with a group of females from the random sample. To avoid sampling bias in shell size, as well as to consider possible migration on the shore (Kojima 1959), the quadrat samples were collected at 3 vertically separated areas: supra-, mid- and sub-littoral. The samples were preserved with $10 \%$ neutralised formalin with excess borax, and were sexed by dissecting using a stereomicroscope. Shell length was used as a size parameter and was measured using digital Vernier callipers in the laboratory. Mean shell lengths in the random sample and the mating group were compared using the Student t-test (2-tailed).

To examine the spawning period at the study site, plankton samples were collected monthly using a submersible water pump $(1.5 \mathrm{~m}$ in depth; $5 \mathrm{~m}$ from the shore-line) from March 1994 to April 1995. To standardise sampling conditions with respect to daily tidal rhythm, samples were always collected at the beginning of ebb tide in the day-time. If an egg capsule was found in the plankton samples, collections were then made on a weekly basis. Pumped seawater (250 l per sampling) was immediately filtered (mesh size: $100 \mu \mathrm{m}$ ) in situ, and fresh planktonic egg capsules (Kojima 1957, Yamaguchi 1967) were subsequently sorted and counted under a dissecting microscope in the laboratory.

Size and morphology of the egg, egg capsule and larval shell were measured in fresh plankton samples collected on March 10 and 15, 1995. Size was measured using a microscope equipped with an ocular micrometer. Terms used for morphological description in the present study follow Reid (1996), with the exception of those concerning the egg capsule. Egg capsules containing 1 egg were referred to as 'common type' and those containing more than $1 \mathrm{egg}$ as 'uncommon type'. These terms do not denote viability or developmental success of the eggs.

In order to study larval development, 20 unsexed adult periwinkles were collected at the study site in January 1994, and reared individually without any food supply in glass beakers $(100 \mathrm{ml})$ containing ambient seawater in the laboratory at 11.0 to $13.0^{\circ} \mathrm{C}$. Ambient seawater used for laboratory rearing was filtered with a glass fibre filter (mesh size $=\mathrm{ca} 1 \mu \mathrm{m}$ ) to prevent propagation of benthic diatoms and protozoans, and to prevent consumption of egg capsules by invertebrate larvae and/or copepods (e.g. Acartia spp.). After spawning, the female was removed from the beaker. The seawater was changed by pouring the egg capsules and seawater through a Müller gauge (mesh size: $330 \mu \mathrm{m}$, this being a fine enough mesh to prevent loss of the egg capsules. The egg capsules were placed in a $2000 \mathrm{ml}$ glass beaker containing fresh ambient seawater, and were reared in the beaker until hatching. Artificial aeration was accomplished by conventional air pump and air stones. Developing eggs were taken from the rearing beaker at $12 \mathrm{~h}$ intervals for microscopic observation.

To measure fecundity, 30 unsexed periwinkles were collected from the study site on February 23, 1995. These were transferred to the laboratory and reared individually in beakers of ambient seawater (100 l) at room temperature $\left(11.0\right.$ to $\left.13.0^{\circ} \mathrm{C}\right)$, the seawater first having been filtered as described above. The bases of the beakers were painted with black enamel to aid observation of the egg capsules, which appeared as tiny white spots floating in the water. At $6 \mathrm{~h}$ intervals, presence of egg capsules in the beaker was checked with an ordinary magnifier. Females which had spawned were transferred into new beakers containing ambient seawater, to examine whether or not multiple spawnings took place. The number of egg capsules spawned by a female was counted using a stereomicroscope.

\section{RESULTS}

\section{Sexual maturation}

In both males and females, minimum shell length at sexual maturation (determined by the presence of mature oocytes and spermatozoa in the gonads) was $6.5 \mathrm{~mm}$. The number of penial glands in males was less than 3 at the minimum sexually mature size (Fig. 1). When reproduction was in progress, the pink-orange albumen and capsule glands could be observed with the naked eye in the female, as could the expanded and swollen penis and penial glands in the male. In May, most capsule glands and penes were markedly reduced, and this condition persisted throughout the summer and autumn until November, when the seawater temperature began to fall below $13.0^{\circ} \mathrm{C}$.

\section{Mating behaviour and sexual selection}

No pre-copulatory courtship was observed. The active male was rejected by the other snail distorting or 


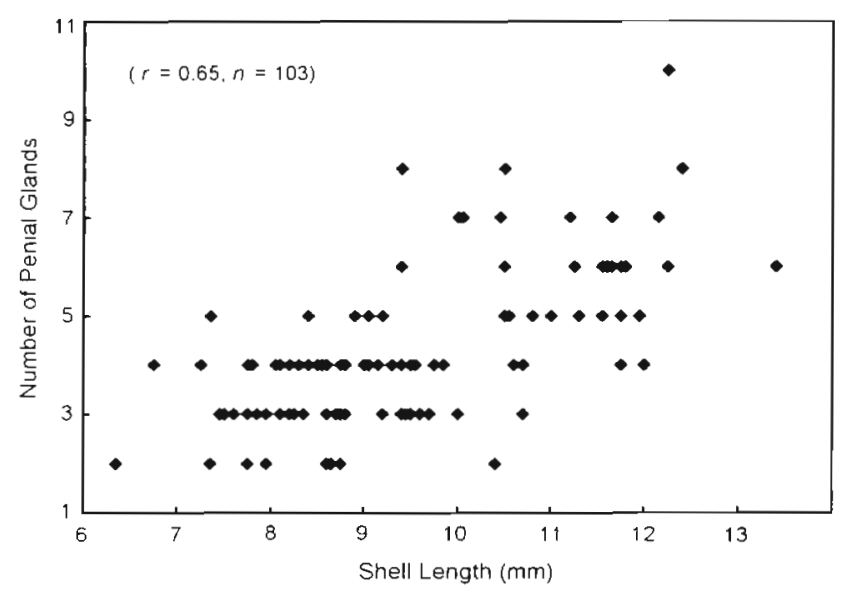

Fig. 1 Littorina brevicula. Relationship between the number of penial glands and the shell length of males in the main breeding season (January 1994) of the Pusan population

twisting its body until the male ceased attempting copulation, withdrew its penis and departed. After departure the male would search for another snail until it eventually found an appropriate sexual partner. During copulation the couples seldom moved. The male is the active partner while the female is passive in the course of mating.

Copulation in laboratory pairs usually lasted for ca $20 \mathrm{~min}$ ( 5 to $32 \mathrm{~min}, \mathrm{SD}=9.68, \mathrm{n}=9$ ). The males did not show any competitive aggressiveness in their behaviour toward other snails in choosing a sexual partner. In the field, copulation usually occurred in seawater ( $\mathrm{n}=236,98.3 \%$ ), but a few copulations occurred out of the water $(n=4,1.7 \%)$.

In the mating group, size of the mates varied between 7.53 and $14.19 \mathrm{~mm}$ in males, and from 7.76 to

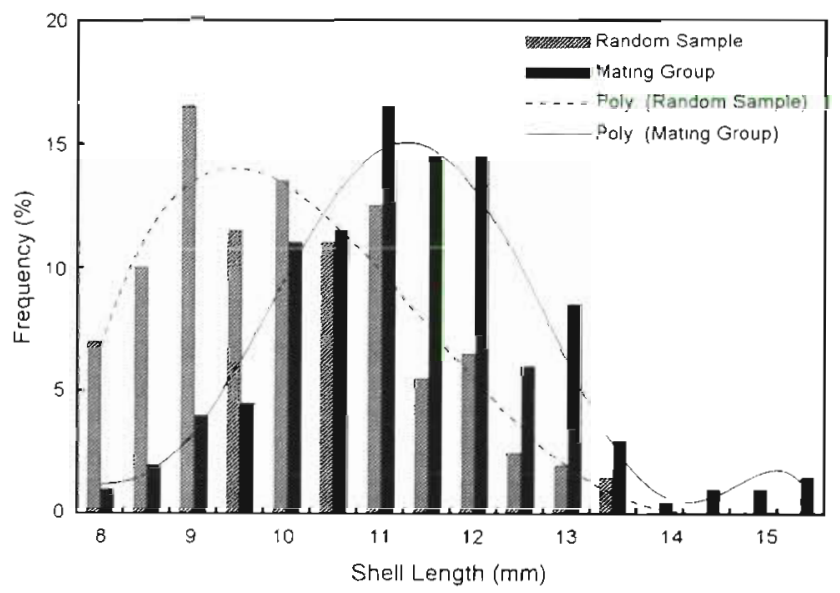

Fig. 2. Littorina brevicula. Size-frequency histogram of females in the random sample (hatched bars) and the mating group (black bars). Females in the mating group means those that participated in copulation in the field

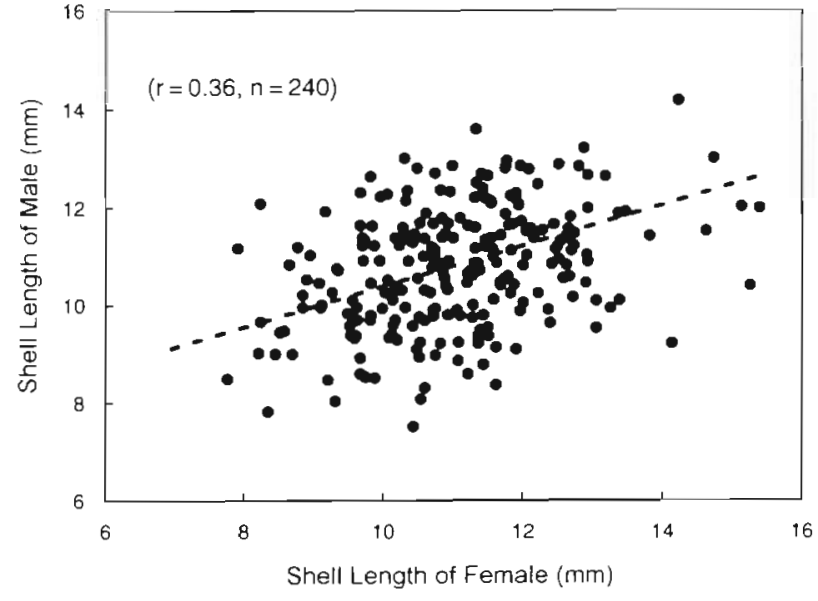

Fig. 3. Littorina brevicula. Relationship between shell lengths of males and females participating in copulation in the field, Pusan, December 1994

$15.39 \mathrm{~mm}$ in females. The main mating group $(70 \%$ of all mating females observed, $n=240$ ) were 9.5 to $12.0 \mathrm{~mm}$ in shell length (Fig. 2). Size of mating females was weakly correlated with that of mating males $(\mathrm{r}=$ $0.36, p<0.05, n=240$; Fig. 3). In the random sample, the peak in the frequency distribution of female size was around $9.76 \mathrm{~mm}$ in shell length $(\mathrm{n}=151)$ (Fig. 2). Mean shell length of females from the mating group was significantly larger than that in the random sample (2-tailed Student $t$-test; $p<0.01$ ) (Fig. 2).

\section{Spawning period}

Mating pairs of Littorina brevicula were found from December to March (Fig. 4) in Pusan. Monthly mean seawater temperature (MMST) during this period was always less than $13.0^{\circ} \mathrm{C}$ (Fig. 4). The maximum number of 110 mating pairs was found in February (MMST: $12.0^{\circ} \mathrm{C}$ ) and March (MMST: $13.0^{\circ} \mathrm{C}$ ) 1995, and none were found from April to November 1994. MMST in this latter period was always above $14.0^{\circ} \mathrm{C}$. The number of mating pairs increased as the MMST decreased below $13.0^{\circ} \mathrm{C}$.

Egg capsules of Littorina brevicula were observed in the plankton samples from January to April, when the seawater temperature began to decrease. They were most abundant in February, when the seawater temperature was less than $12.0^{\circ} \mathrm{C}$ (Fig. 4). The number of egg capsules increased during mid-winter until February and then declined markedly in March. The maximum number of egg capsules, 70 in 250 l, was observed in February 1995 (MMST: $12.0^{\circ} \mathrm{C}$ ), and no egg capsules were observed between May and December 1994 (MMST $>13.0^{\circ} \mathrm{C}$ ). The number of egg capsules increased with the decrease of MMST (Fig. 4). 


\section{Eggs and egg capsules}

The asymmetric, biconvex egg capsule usually contains a spherical egg in its inner central part (Fig. 5). The egg is a dark yellowish-brown, and the egg capsule milky-white and transparent. The capsule consists of 2 membranes (Fig. 5); an outer capsule wall and an inner envelope. The space between the egg and the envelope is semi-transparent, and that between the envelope and the capsule wall is transparent. Fine wrinkles or furrows, which formed fragments of concentric circles, could be observed dorsally on the outer surface of the capsule (Fig. 5A). In the plankton samples, capsules usually contained 1 egg $(>85 \%$, common type; Fig. 5), but some contained 2 or 3 eggs ( $<15 \%$, uncommon type). The uncommon type could be grouped into 2 categories (Fig. 6): those in which the egg capsule simply contained 2 or 3 eggs (Fig. 6C, D) versus those with an egg capsule bearing 2 or 3 eggs each surrounded by an individual egg capsule (Fig. 6B). Egg capsule size of the common type ( $465 \mu \mathrm{m}, \mathrm{SD}=39.7, \mathrm{n}=105$ ) was considerably smaller than that of the uncommon type $(530 \mu \mathrm{m}, \mathrm{SD}=49.9$,
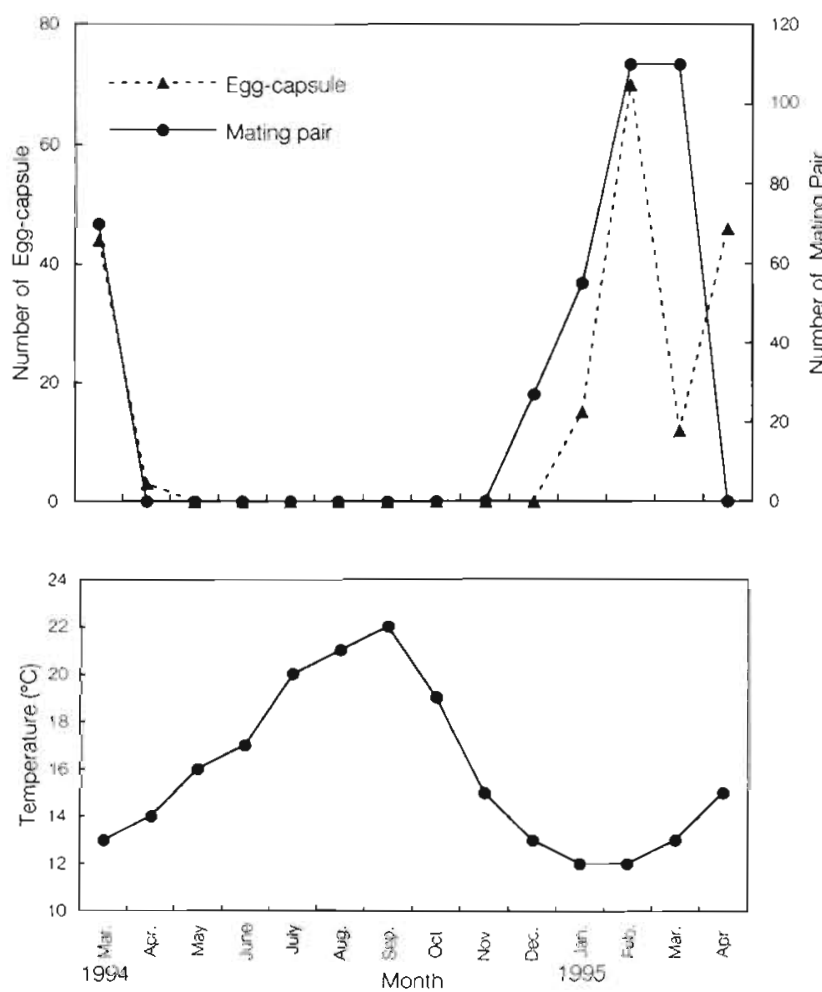

Fig. 4. Littorina brevicula. Monthly fluctuation of the number of egg capsules, the number of mating pairs and seawater temperature in Pusan from March 1994 to April 1995. The values for egg capsules and mating pairs used in the main breeding period (from December to February) are sums of the numbers counted fortnightly $\mathrm{n}=20)$, while egg size of the common type $(135 \mu \mathrm{m}$, $\mathrm{SD}=6.8, \mathrm{n}=105$ ) was slightly larger than that of the uncommon type $(131 \mu \mathrm{m}, \mathrm{SD}=7.3, \mathrm{n}=20)$.

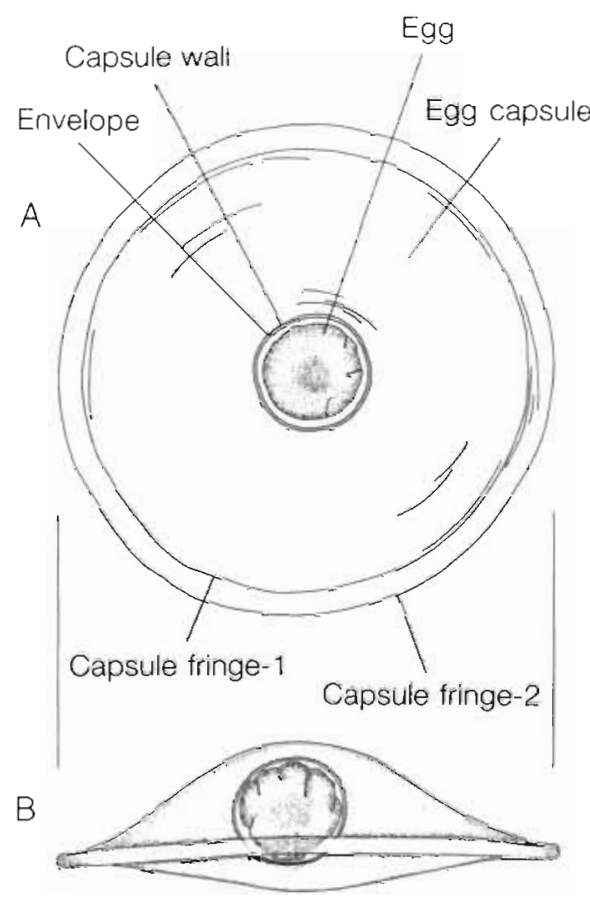

Fig. 5. Littorina brevicula. Morphology of a common type egg capsule. (A) Dorsal view; (B) lateral view. The drawing was made from a plankton sample from Pusan
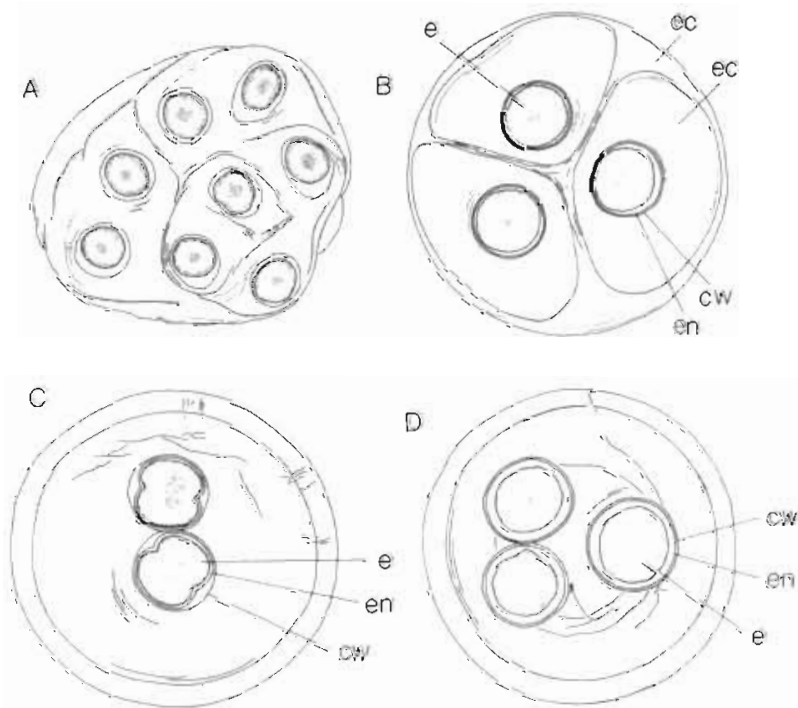

Fig. 6. Littorina brevicula. Morphology of several kinds of uncommon type egg capsules. (A) A mass of the unseparated egg capsules containing several eggs; (B-D) 3 different types of the egg capsule. cw: capsule wall; e: egg; ec: egg capsule; en: envelope 


\section{Larval development}

Embryonic development lasted less than $7 \mathrm{~d}$. The gastrula stage lasted less than $24 \mathrm{~h}$. The trochophore began to form within the egg capsule $3 \mathrm{~d}$ after spawning. At this stage, fine short cilia covering the surface of the incipient velar lobe were observed. The cilia were already used to rotate the trochophore within the capsule. The pre-torsional, early veliger began to form within the egg capsule $4 \mathrm{~d}$ after spawning. At this stage, in addition to the fine short cilia, long hairy cilia were observed at both ends of the non-separated velar lobe, and the hyaline-structured protoconch was also observed. Internal organs, however, were not differentiated in detail at this stage. The post-torsional veliger began to develop about $6 \mathrm{~d}$ after spawning. At this stage, a pair of heavily ciliated velar lobes and an operculum could be observed. Most internal adult organs, including the digestive tract and the muscles, were also observed. The oesophagus was filled with reddishbrown digestive gland. The larva frequently rotated rapidly with the beating of long cilia within the envelope. About $7 \mathrm{~d}$ after spawning, the veliger cast off its capsule and remained in the plankton.

After hatching, the planktonic veliger possessed a large digestive gland. In the stagnant water within a beaker, the veliger moved slightly in a vertical direction via continuous beating of the cilia and velum. When veligers stopped beating the cilia and velum, they immediately sank to the bottom of the water column. During the $2 \mathrm{~d}$ after hatching, there was no observable evidence of feeding behaviour by the veligers.

The protoconch, which consisted of approximately 1.0 whorl (the number of the whorl) with a blunt apex, was somewhat clear, transparent, unornamented, and coarsely grained in its outer surface. Protoconch size of hatched young was up to $120 \mathrm{um}$.

\section{Fecundity}

Female Littorina brevicula spawned an average of 247 egg capsules (101 lo 373, SD $=125, \mathrm{n}=4)$ in the laboratory. All females spawned within 1 to $2 \mathrm{~d}$ after transferring. Successive spawning did not occur in any female which had already produced its egg capsule. On average, the uncommon type comprised $11.8 \%(0.0$ to $33.5 \%, \mathrm{SD}=15.6, \mathrm{n}=4$ ) of the total number of egg capsules produced by a female.

\section{DISCUSSION}

Male Littorina brevicula only began to participate in copulation in the field at a minimum of ca $7.5 \mathrm{~mm}$ in shell length, although histological examination revealed that sexual maturation occurred at ca $6.5 \mathrm{~mm}$ in shell length. This provides additional evidence of continued growth in littorinid species after sexual maturity, unlike certain intertidal gastropods (e.g. Nucella lapillus; Moore 1.938, Crothers 1974). One possible explanation for the difference in minimum shell length between sexual maturation and actual participation in copulation is incomplete functional maturation in males. The presumed function of male penial glands is to secrete a lubricant (Reid 1986). Small (6.0 to $7.0 \mathrm{~mm}$ in shell length) $L$. brevicula possess only 1 or 2 penial glands (Fig. 1), and it is possible that this low number of penial glands cannot physically support copulation.

In contrast to the consistency of sexual roles in littorinid species, partner-searching behaviour apparently varies from species to species. Struhsaker (1966) suggested that active males used chemotactic responses to select females in Littorina species, whereas Erlandsson \& Johannesson (1994) suggested that males of $L$. Iittorea chose an appropriate female by repetitive direct contact with random movement. Dix \& Hamilton (1993) suggested that contact chemoreception was important in the marsh periwinkle Littoraria irrorata in locating mates and food, and in predator avoidance. However, partner-searching behaviour observed in the laboratory in this study supports Erlandsson \& Johannesson's (1994) suggestion and is corroborated by Takada (1995), who observed that males of Littorina brevicula judged the partner's sex after insertion of the penis.

Littorina brevicula may not mate assortatively with respect to shell size at the individual level. Erlandsson \& Johannesson (1994) reported size-assortative mating in only 1 of 3 populations of $L$. littorea examined in Sweden. In the present study, there was a slight correlation ( $r=0.36, n=240$ ) between the size of mating males and females (Fig 3), but the correlation coefficient calculated is much lower than that of Erlandsson \& Johannesson $(r=0.528)$. A possible explanation for the absence of size-assortative mating in $L$. brevicula is the lack of the mechanical constraints on copulation between mates of unequal size suggested by Erlandsson \& Johannesson (1994). The absence of mechanical constraints in $L$, brevicula is suggested by the fact that some of the mating pairs found in the field were remarkably different in size (e.g. female/male size of $14.1 / 9.2,15.2 / 10.4,7.9 / 11.0,8.2 / 12.0 \mathrm{~mm}$ in shell length). At the population level, however, $L$. brevicula may mate assortatively within sub-populations (Takada 1995). The population of $L$. brevicula in Amakusa, Japan, can be behaviourally divided into 2 distinct sub-populations in the main breeding season (winter), and this dimorphism promotes assortative mating at the sub-population level (Takada 1995). 
A decrease to below a critical temperature seems to be an important factor in inducing the spawning of Littorina brevicula and spawning mainly took place in winter over approximately 4 mo (January to April). However, Chase \& Thomas (1995) experimentally demonstrated that temperature influenced spawning duration in L. littorea in the laboratory and so it may be concluded that the duration of spawning of any local population, including the present one, may vary with variation in seawater temperature from year to year

Littorina brevicula spawns mainly in winter at lower temperatures and thus probably spawns once annually, although a few littorinid species do spawn several times a year (e.g. 8 times a year in L. angulifera; Lenderking 1954). Low temperature has been a trigger to spawning in barnacles (Crisp 1957) and L. Littorea (Williams 1964). Fretter (1984) suggested that reproductive seasonality is related to the geographic origin of the species. According to this suggestion, L. brevicula may originate from a northern cold area of the boreal Pacific. In most marine invertebrates, reproduction tends to be confined to narrower temperature ranges than the majority of other life processes (Kinne 1970). The thermal range of reproduction in $L$. brevicula is 11.0 to $12.0^{\circ} \mathrm{C}$. Therefore, the result of the present study is probably an important additional evidence to the foregoing tendency of reproduction, narrow temperature range (only $1.0^{\circ} \mathrm{C}$ in L. brevicula), with a clear correlation between critical temperature and reproduction. Even though temperature is often mentioned as an important factor in gonadal development, few histochemical and cytological data exist for prosobranchs (Webber 1977).

Egg capsules of Littorina brevicula were first collected from plankton samples a month after the first mating pair was found in the field. The time-lag between the first appearance of mating pairs and that of the planktonic egg capsules varies from species to species in the family Littorinidae. For instance, in laboratory experiments spawning took place $1 \mathrm{wk}$ after copulation in L. brevicula (Kojima 1957), but after only a few hours in L. obtusata, 2 to $12 \mathrm{~h}$ in L. littorea (Thorson 1946), and $4 \mathrm{~h}$ in L. angulifera (Lenderking 1954). Regarding the time-lag between mating and spawning, Fretter \& Graham (1962) noted that it is well known that female prosobranch gastropods have the capacity to store sperm for short periods. Borkowski $(1971,1974)$ reported that the receptaculum seminis of the female stored and nourished the sperm until they were used in fertilisation, in L. littorea, L. ziczac, $L$. angulifera and L. flava. Strathmann (1987) hypothesised that in mesogastropods and neogastropods (now called Caenogastropoda) sperm are received during copulation and might be stored in the female for some time before fertilisation.
It is well documented that the number of eggs in an egg capsule varies. Kojima (1957) found a maximum of 5 eggs per capsule from the Asamushi (Japan) samples, and Yamaguchi (1967) reported a maximum of 2 eggs per capsule in Moroiso (Japan) A form of the uncommon type with 2 or 3 eggs per capsule observed in the present study agrees well with the drawings of an 'abnormal egg capsule' containing 2 eggs described by Yamaguchi (1967). Using the term 'abnormal' to describe egg capsules which contain more than 2 eggs may not be appropriate in the absence of any evidence of associated physiological and/or developmental abnormalities.

In the present study, the intra-capsular embryonic development of Littorina brevicula lasted approximately $7 \mathrm{~d}$ until hatching of the planktonic veliger occurred (at 11.0 to $13.0^{\circ} \mathrm{C}$ ). Results of the present study were very similar to those of Kojima $(1957 ; 8 \mathrm{~d}$ at $\left.10.0^{\circ} \mathrm{C}\right)$ and Golikov $(1976 ; 8$ to $10 \mathrm{~d}$; from Tatarenkov 1995). The difference of $1 \mathrm{~d}$ in developmental period between the present study and these latter 2 populations may be due to differences in rearing temperature (e.g. 11.0 to $13.0^{\circ} \mathrm{C}$ vs $10.0^{\circ} \mathrm{C}$ in Kojima's study).

Unfortunately, the exact location of the hatching pore (upper or lower side of the biconvex shape) through which the veliger of Littorina brevicula emerged was not observed. The upper and lower side of the egg capsule could not be distinguished after the veliger hatched because the capsule was seriously ruptured and fractured. However, the positioning of the rupture pores was consistent with the observation by Murray (1979) in L. scutulata that the pore is centrally located on one surface of the egg capsule. Kojima (1957) noted that the larvae hatch out through the concave spot at the centre of the bottom (lower side in the present study) of the capsule. With regard to the rapid rotating movements of the larvae within the envelope, Murray (1979) suggested that abrasion of the inner capsule wall (termed 'envelope' in the present study) by the shell (protoconch) might be an important mechanism in the veliger's exit from the capsule. Tattersall (1920), however, reported that the bursting of capsules of $L$. littorea was caused by increased osmotic pressure.

The presence of pelagic egg capsules in Littorina brevicula agrees well with previous reports by Mileikovsky (1975) and Underwood (1979). Mileikovsky (1975) reported in his comprehensive review paper that of the littorinid gastropods living at high intertidal levels, the majority (34 of 39 species) had pelagic egg capsules.

Although no sign of feeding was observed in the laboratory during the $2 \mathrm{~d}$ after hatching, the veliger of Littorina brevicula might feed whilst in the plankton because the protoconch is known to grow from ca $120 \mu \mathrm{m}$ 
at hatching (the present study) to ca $360 \mu \mathrm{m}$ at settlement (Reid pers. comm.). For a few days after hatching, the veliger might be fuelled by yolk material such as the digestive glands (lecithotrophy), and only then commence planktotrophic feeding.

The number of egg capsules produced by a female Littorina brevicula (mean: 247; 101 to 373 ; SD $=125$; $n=4$ ) in the present study varied widely between individuals, but seemed to exceed that reported by Yamaguchi (1967; 'several dozen'). However, the number of spawned females used in the present study was not sufficient to calculate a reliable mean value. Extreme individual variability in egg production has also been reported in $L$, neritoides in North Wales, UK, by Hughes \& Roberts (1980) who hypothesized that much of this variability could be attributed to the effects of unpredictable weather conditions upon feeding activity. Underwood (1979) noted that in prosobranch gastropods, including Littorina species, the size of the breeding members of a species must influence the number of eggs which can be produced. The present study, however, did not demonstrate a relationship between the foregoing 2 factors because sufficient breeding females could not be obtained.

Acknowledgements. We thank Dr D. G. Reid, British Museum of Natural History, and Prof. R. N. Hughes, School of Biological Science, University of Wales, for their constructive comments and suggestions on an earlier draft of this manuscript, and we thank Dr H. K. Kang, Miss A. Kazem and Mr H. J. Kang for their kind assistance during the preparation of this manuscript. We are also especially grateful to anonymous reviewers for improving the manuscript.

\section{LITERATURE CITED}

Abbott RT (1954) Review of the Atlantic periwinkles, Nodilittorina, Echininus, and Tectarius. Proc US Natl Mus 103 : $449-464$

Abe $N$ (1935) The colony of the Littorina: Littorivaga brevicula (Philippi). Sci. Rep Tohoku Univ Fourth Ser (Biol) 9 279-296

Borkowskı TV (1971) Reproduction and reproductive periodicity of South Floridian Littorinidae (Gastropoda: Prosobranchia). Bull Mar Sri 21:827-840

Borkowski TV (1974) Growth, mortality, and productivity of south Floridian Littorinidae (Gastropoda; Prosobranchia). Bull Mar Scl 24:409-438

Borkowski TV, Borkowski MR (1969) The Littorina ziczac species complex. Veliger 11:408-414

Chase ME, Thomas MLH (1995) The effect of the rate and onset of temperature increase on spawning of the periwinkle, Littorina littorea (L.). J Exp Mar Biol Ecol 186:277-287

Crisp DJ (1957) Effect of low temperature on the breeding of marine animals. Nature 179:1138-1139

Crothers JH (1974) On variation in Nucella lapillus (L.): shell shape in population from the Bristol Channel. Proc Malacol Soc Lond 41:157-170

Dix TL, Hamilton PV (1993) Chemically mediated escape behaviour in the marsh periwinkle Littoraria irrorata Say.
J Exp Mar Biol Ecol 166:135-149

Erlandsson J, Johannesson K (1994) Sexual selection on female size in a marine snail, Littorina littorea (L.). J Exp Mar Biol Ecol 181:145-157

Fretter V (1984) Prosobranchs. In: Tompa AS, Verdonk N.H (eds) The Mollusca, Vol 7. Academic Press, London, p. $1-35$

Fretter V, Graham A (1952) British prosobranch molluscs their functional anatomy and ecology. Ray Society, London

Golikov AN (1976) Gastropoda. The animals and plants of Peter the Great Bay. Nauka, Leningrad

Hirai $E$ (1963) On the breeding seasons of invertebrates in the neighbourhood of the marne biological station of Asamushi. Sci Rep Tohoku Univ Fourth Ser (Biol) 29: 369-375

Hughes RN, Roberts DJ (1980) Growth and reproductive rates of Littorina neritoides (L.) in North Wales. J Mar Biol Assoc UK 60:591-599

Kinne O (1970) Temperature: animals: invertebrates. In Kinne $O$ (ed) Marine ecology, Vol 1, Part 1. Wiley-Interscience, London, p 407-514

Kojima Y (1957) On the breeding of a periwinkle, Littorivaga brevicula (Philippi). Bull Mar Biol Stn Asamushi 8:59-62

Kojima Y (1959) The relation between seasonal migration and spawning of a periwinkle, Littorina brevicula (Philippi). Bull Mar Biol Stn Asamushi 9:183-186

Kojima Y (1960) On the reproduction of periwinkles, Littorinidae, Gastropoda. Bull Mar Biol Stn Asamushi 10:117-120

Lebour MV (1935) The breeding of Littorina neritoides. J Mar Biol Assoc UK 20:373--378

Lebour MV (1945) Eggs and larvae of some prosobranchs from Bermuda. Proc Zool Soc Lond 114:462-489

Lenderking RE (1954) Some recent observations on the biology of Littorina angulifera Lam. of Biscayne and Virginia Keys, Florida. Bull Mar Sci Gulf Caribb 3:273-296

Mileikovsky SA (1975) Types of larval development in Littorinidae (Gastropoda: Prosobranchia) of the world ocean, and ecological patterns of their distribution. Mar Biol 30: $129-135$

Moore HB (1938) The biology of Purpura lipillus. II. Growth. $J$ Mar Biol Assoc UK 23:57-66

Murray TE (1979) Evidence for an additional Littorina species and a summary of the reproductive biology of Littorina from California. Veliger 21:469-474

Pelseneer P (1911) Recherches sur l'embryologie des gastropodes. Mem Acad R Belgique, Classe Sci Ser II 3(4): $1-167$

Reid DG (1986) The littorinid molluscs of mangrove forests in the Indo-Pacific Region. Brit Mus Nat Hist, London

Reid DG (1996) Systematics and evolution of Littorina. Ray Society, London

Rosewater J (1970) The family Littorinidae in the Indo-Pacific. Part I. The subfamily Littorininae. Indo-Pac Mollusca 2: 417-506

Strathmann MF (1987) Reproduction and development of marine invertebrates of the Northern Pacific Coast. Univ Washington Press, Seattle

Struhsaker JW (1966) Breeding, spawning, spawning periodicity and early development in the Hawaiian Littorina: $L$. pintato (Wood), L. picta Philippi and L. scabra (Linne). Proc Malacol Soc Lond 37:137-166

Takada Y (1995) Seasonal migration promoting assortative mating in Littorina brevicula on a boulder shore in Japan. Hydrobiologia 309:151-159

Tatarenkov A (1995) Genetic heterogeneity in populations of Littorina brevicula (Philippi) (Mollusca: Gastropoda) in the 
northern part of Peter the Great Bay (Sea of Japan). Veliger 38:85-91

Tattersall WM (1920) Notes on breeding habits and life history of the periwinkle. Dept Agri Tech Inst Ireland Fish Brit Sci Inves 1:1-11

Thorson G (1946) Reproduction and larval development of Danish marine bottom invertebrates. Meddr Kommn Danm Fisk-og Havunders (Plankton) 4

Tokioka T, Habe T (1953) Droplets from the plankton net. 11. A new type of Littorina capsula. Publ Seto Mar Biol Lab 3: $55-56$

Editorial responsibility: Otto Kinne (Editor),

Oldendorf/Luhe, Germany
Underwood AJ (1979) The ecology of intertidal Gastropoda. In: Russel FR, Yonge $M$ (eds) Advances in marine biology, Vol 16. Academic Press, London, p 111-210

Webber HH (1977) Gastropoda: Prosobranchia. In: Giese AC, Pearse JS (eds) Reproduction of marine invertebrates, Vol 4. Academic Press, London, p 1-97

Williams EE (1964) The growth and distribution of Littorina littorea (L.) on a rocky shore in Wales. J Anim Ecol 33: 413-432

Yamaguchi M (1967) Egg capsules of a periwinkle, Littorina brevicula, in plankton samples. Venus 25:73-76

Submitted: May 14, 1998; Accepted: July 7, 1998

Proofs received from author(s): September 21, 1998 